ORIGINALS

\title{
UDP-Glucose-Glucan Glucosyl-Transferase Activity of Polymorphonuclear Leukocytes from Diabetic Subjects
}

\author{
V. Esmann, C.J. Hedeskov and M. Roselu Perez \\ Department of Medicine, Marselisborg Hospital, University \\ of Aarhus Medical School, Aarhus (Denmark) \\ and Cátedra de Bioquímica de la Facultad de Farmacia, Universidad de Barcelona, Barcelona (Spain) \\ Received: November 16, 1967
}

Summary. 1. In normal leucocytes, glycogen-transferase was only found in the glucose-6-phosphate dependent $D$-form. An increase in activity was observed within 30 min after glucose feeding, and is assumed to be mediated through the action of released insulin. A late secondary increase in activity occurred simultaneously with an increase in serum growth hormone. -2 . In most diabetic leucocytes, glycogen-transferase was found in both the I- (independent of glucose-6-phosphate) and D-form. The $I+D$ activity was low in uncontrolled diabetes and increased in response to insulin treatment. The I-activity was low immediately upon isolation of the leucocytes, but increased during incubation of the enzyme, especially in the presence of $\mathrm{Mg}^{2+}$; indicating that diabetic leucocytes possess transferase-D phosphatase activity in contrast to normal cells. The D to I transformation of the enzyme was greatly increased by insulin treatment. $-3 . K_{m}$ for UDPG and $K_{a}$ for glucose-6-phosphate did not vary between normal and diabetic leucocytes. - 4. The $D$ to I interconversion of the incubated enzyme from diabetic cells was found to depend on the concentration of ATP and $A D P$ in the incubation medium. It is suggested, that the activating effect of $\mathrm{Mg}^{2+}$ on the $\mathrm{D}$ to I transformation is due to an activation of an endogenous ATP-ase and adenylate kinase.

Activité UDP-glucose-glucan glucosyl-transférase de leucocytes polynucléaires de sujets diabétiques

Résumé. 1. Dans les leucocytes normaux, la glycogènetransférase n'a été trouvée que sous la forme-D glucose-6phosphate-dépendante. On a observé une augmentation de l'activité dans les $30 \mathrm{~min}$ consécutives ̀े l'absorption de glucose, et on a supposé qu'elle était provoquée par l'action de l'insuline libérée. Une augmentation secondaire ultérieure de l'activités'est produite en même temps qu'une augmentation de l'hormone de croissance du sérum. 2. Dans la plupart des leucocytes de diabétiques, la glycogène-transférase a été trouvée à la fois sous la forme-D et la forme-I (indépendante du glucose-6-phosphate). L'activité $I+D$ était faible dans le diabète non-contrôlé et augmentait en réponse à un traitement insulinique. L'activité-I était faible immédiatement apròs isolement des leucocytes, mais augmentait pendant l'incubation de l'enzyme, particulièrement en présence de $\mathbf{M g}^{2+}$, indiquant que les leucocytes de diabétiques possèdent une activité
transférase-D phosphatase contrairement aux cellules normales. La transformation de l'enzyme de D en I était fortement accue par le traitement insulinique. $-3 . K_{m}$ pour l'UDPG et $\mathbf{K}_{a}$ pour le glucose-6-phosphate ne variaient pas entre les leucocytes normaux et diabétiques. 4. La transformation de $\mathrm{D}$ en I de l'enzyme incubé à partir des cellules de diabétiques s'est avérée dépendre de la concentration d'ATP et d'ADP dans le noilieu d'incubation. On suggère que l'effet activant du $\mathrm{Mg}^{2+}$ sur la transformation de $D$ en I est due à une activation d'une A'TPase endogène et d'une adénylate kinase.

Die Aktivität der UDP Glucose-Glucan-Glucosyl-Trans. ferase in polymorphkernigen Leukozyten von Diabetikern

Zusammenfassung. 1. In normalen Leukozyten wurde die Glycogen-Transferase nur in der Glucose-6-Phosphatabhängigen Form D angetroffen. Thre Aktivität steigt in den $30 \mathrm{~min}$ nach oraler Glucosezufuhr an, was auf die Insulinfreisetzung bezogen wird. Eine zweite spätere Aktivitätssteigerung erfolgte gleichzeitig mit dem Anstieg der Wachstumshormonspiegel im Serum. - 2. In den meisten diabetischen Leukozyten fand sich die GlykogenTransferase in der D und der I Form (Glucose-6-Phosphat unabhängig). Dio I+D Aktivität war bei entgleistem Diabetes niedrig und stieg nach Insulinbehandlung an. Unmittelbar nach der Isolierung der Leukozyten wurde nur eine geringe I Aktivität festgestellt, diese steigerte sich aber während der Inkubation des Enzyms, vor allem wenn diese in Gegenwart von $\mathrm{Mg}^{2+}$ erfolgte, was dafür spricht, daß diabetische Leukozyten im Gegensatz zu normalen Transferase-D Phosphatase Aktivität besitzen. Die Überführung der D in die I Form des Enzyms wurde durch Insulinbehandlung stark gefördert. - - 3. Die $\mathbf{K}_{m}$ für UDPG und $\mathrm{K}_{a}$ für Glucose-6-Phosphat unterschieden sich bei normalen und diabetischen Leukozyten nicht. 4. Es wurde festgestellt, daß die D zu I Umwandlung während der Inkubation des aus diabetischen Zellen gewonnenen Enzyms vom Gehalt dos Mediums an ATP und ADP abhängt. Die Förderung der I zu D Umwandlung durch $\mathrm{Mg}^{2+}$ scheint auf der Aktivierung einer endogenen ATPase und einer Adenylat-Kinase zu beruhen.

Key-words: Polymorphonuclear leucocytes, glycogen transferase, diabetes, insulin action, serum growth hormone, glycogen transferase D phosphatase.
The enzyme uridine diphosphate glucose: $\alpha-1,4$ glucan $\alpha$-4-glucosyltransferase (EC 2.4.1.11, glycogen synthetase or transferase) exists in two enzymically interconvertible forms in muscle [15-18] and liver [9], and the interconversion system has been characterized as a phosphorylation/dephosphorylation reaction on a serine residue of the enzyme $[6,10]$.
The I form of the enzyme is independent of glucose6-phosphate for activity. The proportion of the total enzyme activity which is present as the $I$ form is increased by insulin [22]. In liver this effect has been demonstrated as early as two hours after the injection of insulin to alloxan diabetic rats [20], and 10 minutes after the start of an insulin infusion to normal dogs [3]. 
With muscle extracts as well as with the rat hemidiaphragm in vivo, the insulin effect has been elicited within $5 \min [23,7]$.

The $D$ form of the enzyme is considered the less active form as it requires glucose-6-phosphate for activity. In liver, $K_{m}$ for UDPG is higher for the $\mathrm{D}$ than for the $\mathrm{I}$ enzyme. In muscles, however, the reverse is the case $[9,3]$. In liver tissue no difference in $D$ activity between normal fed and fasted rats was found, but insulin administration increased transferase $D$ within two hours [20], i.e. the increase in $I+D$ activity was much larger than the simultaneous increase in I activity. The $I+D$ activity was unchanged when the insulin effect was looked for within $10 \mathrm{~min}$ [3], and, similarly, was not detectable in muscle tissue 5 min after an insulin injection [2].

An action of insulin in vitro on the $\mathrm{D}$ to I conversion system has been found with rat hemidiaphragms [7] and HeLa cells [2], but reportedly not with liver tissue [20].

The prompt action of insulin in the direction of favouring the appearance of the dephosphorylated form of the enzyme has been amply discussed by BisHor and Larner [3]. Adenosine $3^{\prime}, 5^{\prime}$-cyclophosphate stimulates the transferase I kinase, and insulin may be thought of as acting by lowering the concentration of the activator. Recent experimental evidence [7], however, has shown that the concentration of cyclic-adenylate actually increases concomitantly with the insulin mediated D to I conversion in rat diaphragm. Evidence is now emerging [23], that insulin may change the form of synthetase I kinase from an independent to a less active form dependent on cyclic adenylate. In these experiments, insulin did not change the activity of transferase $\mathrm{D}$ phosphatase.

It has previously been found, that the form of transferase present in normal human polymorphonuclear (PMN) leucocytes is absolutely dependent on glucose-6-phosphate for activity, and that no D to I conversion system exists in these cells [14]; whereas such a system is readily found in normal human lymphocytes and is activated by $\mathrm{Mg}^{2+}(r e f .15)$. The present experiments demonstrate the appearence of a $\mathrm{D}$ to I conversion system in PMN leucocytes from diabetic subjects and its dependence on the metabolic state of the patient. Data are also given on the effect of fasting and feeding on the level of transferase $\mathbf{D}$ in normal leucocytes, together with an explanation of the effect of $\mathrm{Mg}^{2+}$ on the $\mathrm{D}$ to $\mathrm{I}$ conversion. A preliminary report of these experiments has appeared [13].

\section{Material and Methods}

Material. The investigation comprised leucocytes from 16 diabetic patients, one of whom (IHJ) was investigated thrice with intervals of one year. Detailed information on the age of the patients, the age at onset and the duration of the diabetes, the insulin treatment, the occurrence of late diabetic manifestations together with information on the metabolic state of the patients at the time of the investigations appears in Table 1. Summarizing, 4 patients had maturity-onset diabetes (over 40 years) and 12 were juvenile diabetics. The duration of diabetes in the group of juvenile diabetics was $0-1$ year in two cases, $1-5$ years in four cases and 14-44 years in 6 cases. Similarly, the known duration of the disease in the four patients with maturity-onset diabetes was three months, and 8,17 , and 28 years, respectively. One patient (PMN) had had diabetes for 6 months and was investigated after the termination of a remission period of five months. All patients needed insulin for the regulation of their blood sugar and were held on NPH or lente insulins, eventually supplemented with regular insulin. In most cases the duration of insulin treatment coincided with the duration of the disease. In the group of patients with recently diagnozed diabetes, however, the length of insulin medication ranged from 4-20 days only. The patient (PMN), who was investigated after a remission, had received insulin for 48 days 6 months previously.

All patients were investigated on insulin treatment, and in 9 cases the investigation was repeated after insulin had been withheld for $36-48 \mathrm{~h}$. The degree of metabolic control has been evaluated from the averages of the blood sugars at $7-8$ a.m. and $4-5 \mathrm{p} . \mathrm{m}$. the last four days before the investigation on insulin, and these figures together with the actual fasting, morning blood sugar on the day of investigation are given in Table 1. The table also shows the fasting, morning blood sugar for the diabetics, who were also investigated after withdrawal of insulin. In one case (JSH), however, the patient went into precoma and was investigated at 5 p.m., and the corresponding blood sugar is given instead. In four cases (IHJ 1965, MAS, $\mathrm{BWS}$, and MAP) the first investigation was done when the patients were out of insulin treatment and the second investigation was made when the blood sugar, in 2-4 days, had been brought to normal with insulin. In these eases, naturally, no values appear for the average blood sugar for the last four days of insulin treatment.

It is apparent from Table 1, that the blood sugars of nearly all the patients were satisfactorily low for the assay of transferase on insulin medication, and that the 9 patients investigated after withdrawal of insulin all had high fasting, morning blood sugars.

The investigation also included an examination of 10 normal, nonglucosuric subjects chosen among laboratory personnel and students.

Methods. Leucocytes (approx. 85\% PMIN cells) were isolated and sonicated, and the activity of transferase was measured as radioactivity incorporated into glycogen from ${ }^{14} \mathrm{C}$-labelled UDPG, without (I form) and with $0.01 \mathrm{M}$ glucose-6-phosphate ( $\mathrm{D}$ form) present in the assay mixture, as previously described [14]. In 


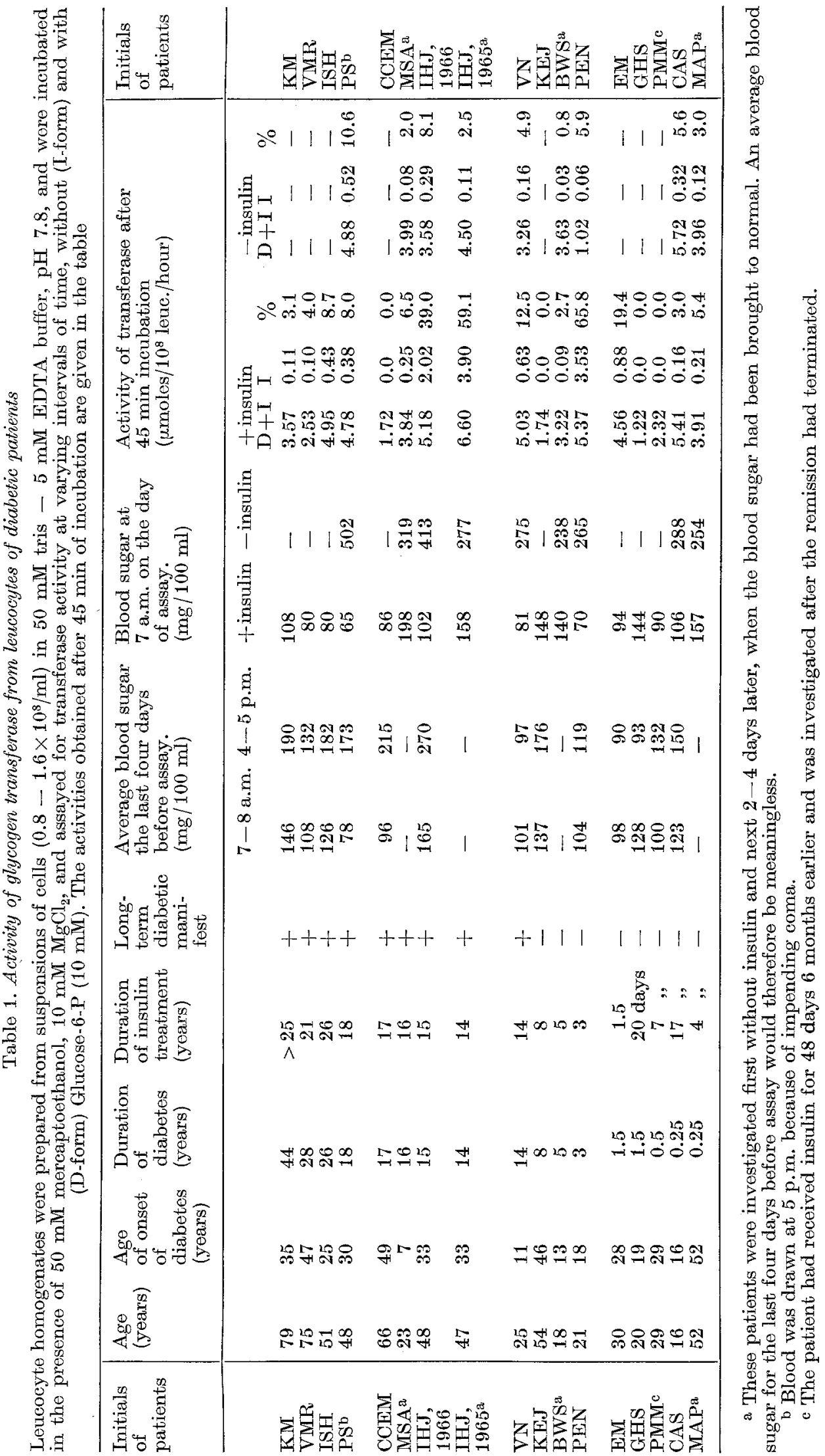


addition, the enzyme was incubated for $60 \mathrm{~min}$ at $30^{\circ}$ with $5 \times 10^{-2} \mathrm{M}$ mercaptoethanol and $1 \times 10^{-2} \mathrm{M}$ $\mathrm{MgCl}_{2}$, and assayed at intervals for both $\mathrm{D}$ and $\mathrm{I}$ form. In some experiments parallel incubations with and without added $\mathrm{Mg}^{2+}$, or with or without the addition of a $\mathrm{Mg}$-dependent $\mathrm{A}^{\top} \mathrm{TP}$-ase and adenylate kinase from kidney, were performed. These enzymes had an activity of 20 and $13 \mu$ moles ATP/mg protein per hour, respectively.

Blood sugars were determined conventionally on. capillary blood, except in oral glucose tolerance tests, when venous blood was used. In some experiments plasma growth hormone was assayed by an immunological technique [24], and ATP by a luciferase method [11].

\section{Results}

Total transferase activity. The total $(\mathrm{D}+\mathrm{I})$ activity of transferase measured immediately after preparation of the leucocyte homogenate was not significantly different from the normal in a series of 17 preparations from 16 diabetics on insulin. Howerer, 9 diabetics, who were investigated both on and off insulin treatment, showed a nearly statistically significant decrease in $\mathrm{D}+\mathrm{I}$ activity upon withdrawal of insulin (Table 2).

Table 2. Activity of glycogen transferase from leucocytes of normal and diabetic patients ${ }^{a}$

\begin{tabular}{|c|c|c|c|c|}
\hline & $\mathrm{n}$ & $\begin{array}{l}\text { Total }(\mathrm{D}+\mathrm{I}) \\
\text { ( } \text { moles } / \mathbf{1 0}^{8} \mathrm{I} \\
+ \text { insulin }\end{array}$ & $\begin{array}{c}\text { transferase } \\
\text { euc. } / \mathrm{h} \pm \mathrm{s.e.1} \\
\text {-insulin }\end{array}$ & $\begin{array}{l}\text { activity } \\
m \text {. and range) } \\
\text { Difference }\end{array}$ \\
\hline Diabetics & 17 & $\begin{array}{c}3.48 \pm 0.41 \\
(0.72-6.05)\end{array}$ & & \\
\hline Normals & 10 & $\begin{array}{c}2.85 \pm 0.54 \\
(1.06-4.92)\end{array}$ & & \\
\hline \multicolumn{5}{|c|}{$\begin{array}{l}\text { a) ef. legend to Table } 1 \text {. } \\
\text { b) } t=2.25 ; t_{0.05}=2.30\end{array}$} \\
\hline
\end{tabular}

$D$ to $I$ conversion of transferase. With normal leucocytes no I activity was detectable, but with leucocytes from insulin-treated diabetics a small but significant I activity of $1.5 \% \pm 0.5$ of the total activity was found immediately after isolation of the cells.

Upon incubation of the leucocyte preparation (Fig. 1) a large $D$ to I conversion took place in several homogenates from insulin-treated diabetic patients, and it was observed that the addition of $\mathrm{Mg}^{2+}$ to the incubation medium increased both the total enzyme activity and the D to I transformation. Addition of ATP$\mathrm{Mg}$ caused a fast and complete disappearence of the I activity, and also, more slowly, a decrease in total enzyme activity, especially in the incubation without added $\mathrm{Mg}^{2+}$. This means that not all the disappeared I activity has been converted into the $D$ form of the enzyme.

Fig. 2 illustrates that insulin deprival leads to a decrease in the $\mathrm{D}-\mathrm{I}$ activity, and to an almost complete abolishment of the D to I transformation. Exact-

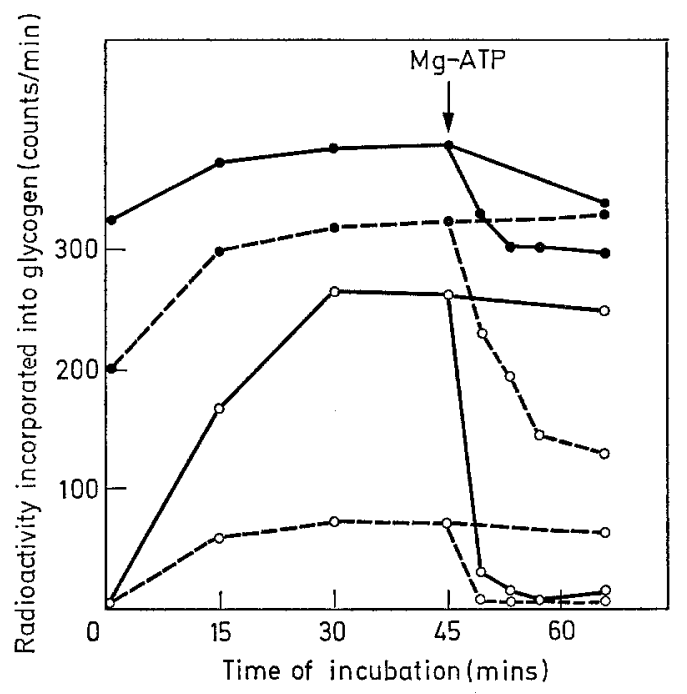

Fig. 1. Effect of $\mathrm{Mg}^{2+}$ on the D to I conversion of glycogen synthetase from leucocytes of an insulin-treated diabetic patient (PEN). The enzyme was prepared by sonicating a suspension of $0.936 \times 10^{8}$ leucocytes $(83 \%$ PMN) per $\mathrm{ml}$ in $50 \mathrm{mM}$ Tris - $5 \mathrm{mM}$ EDTA buffer ( $\mathrm{pH} 7.8$ ), and was incubated for $65 \mathrm{~min}$ with $50 \mathrm{mM}$ mercaptoethanol, with or without $10 \mathrm{mM} \mathrm{MgCl}_{2}$. At $45 \mathrm{~min} 2.7 \mathrm{mM}$ ATP and $5.4 \mathrm{mM} \mathrm{MgCl}_{2}$ was added to part of the incubated enzyme. At intervals transferase was assayed in a system containing $50 \mu \mathrm{l}$ of enzyme (corresponding to $4.7 \times 10^{6}$ leucocytes), $4 \mathrm{mM}$ UDPG, and $7 \mathrm{mM}$ glucose-6-phosphate when present. $0_{---}-0$, I enzyme; $0-1$ I enzyme $+\mathrm{Mg}^{2+}$; -----0 , total enzyme $(\mathrm{I}+\mathrm{D})$; , total enzyme $(I+D)+M^{2+}$

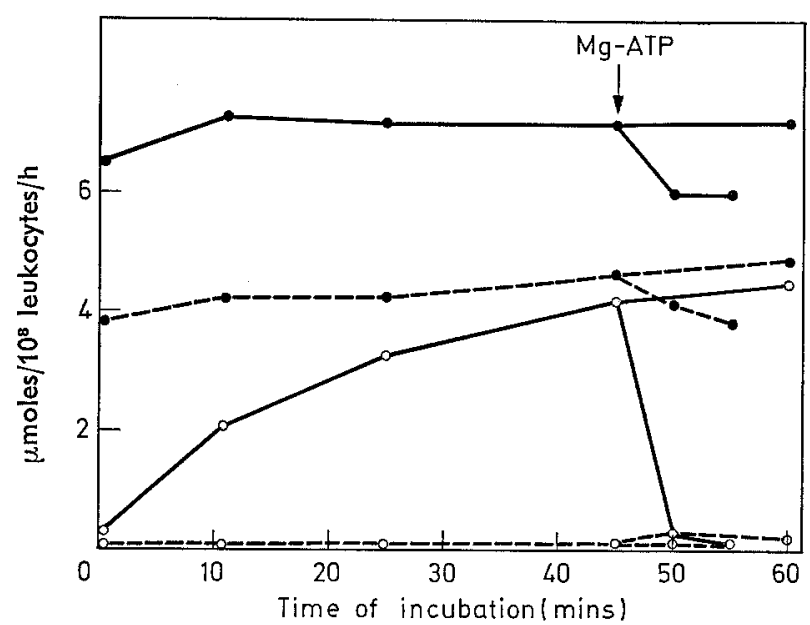

Fig. 2. Effect of insulin treatment on the $\mathrm{D}$ to $\mathrm{I}$ conversion of leucocyte transferase from patient IHJ (1965). The enzyme was prepared from leucocytes isolated when insulin had been withheld for $39 \mathrm{~h}$, and again $48 \mathrm{~h}$ later when the blood sugar had been brought to normal by insulin treatment. The incubation mixture contained buffer, mercaptoethanol, $\mathrm{Mg}^{2+}$, and enzyme from $1.49 \times 10^{8}$ leucocytes (89\% PMN) and $2.08 \times 10^{8}$ leucocytes $(84 \%$ PMN) per mal, respectively. Otherwise as in Fig. 2. $0-\ldots+-0$, I enzyme without insulin; $0-0$, I enzyme with insulin; - - - - - I $+D$ enzyme without insulin; - I+D enzyme with 
ly the same pattern was observed one year later, when the investigation was repeated in the reverse order (IHJ 1966), i.e. first on, then off insulin.

The $\mathrm{D}$ to I transformation is maximal after 45 min incubation of the enzyme in the presence of $\mathrm{Mg}^{2+}$. Table 1 shows the I activity at this time for all the patients. Four patients showed no D to I conversion, whereas homogenates from 8 patients reached an I activity of less than $10 \%$ of the $\mathrm{D}+\mathrm{I}$ activity, and those from 4 patients reached between 10 and $66 \% \mathrm{I}$ activity. The average I activity at $45 \mathrm{~min}$ was $14 \% \pm 5$ of the total activity. The results of the addition of ATP-Mg, which was done in each experiment, are not shown in the table. In each case the I activity immediately disappeared, which proved that even the low $I$ activities measured in some cases were not artifacts.

In 7 out of 9 experiments done on patients both on and off insulin treatment, the $\mathrm{I}$ activity measured after $45 \mathrm{~min}$ incubation of the leucocyte preparation showed a decrease, when insulin was withheld. The decrease in the average percentage I activity was from $22.5 \%$ to $4.8 \%(p<0.1)$. The extent of the $\mathrm{D}$ to I transformation was not correlated to the age of the patients, the age of onset of the diabetes, the duration of the disease, the occurrence of late diabetic manifestations or to the duration of insulin treatment.

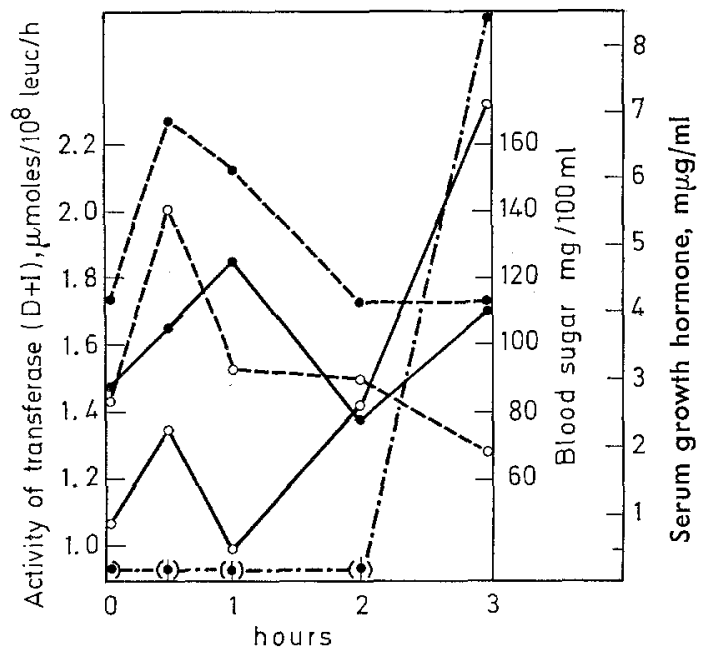

Fig. 3. Effect of glucose on total $(I+D=D)$ transferase activity in leucocytes from two normal subjects. An oral glucose tolerance test with $100 \mathrm{~g}$ glucose was performed, and simultaneously transferase activity was determined in leucocytes immediately after preparation of the homogenate. In one case serum growth hormone was also determined. Values below $0.5 \mathrm{~m} \mu \mathrm{g} / \mathrm{ml}$ are not detectable. $0-\ldots--0$, blood sugar; $0-0$, corresponding transferase D activity; - $-\ldots-\ldots$, blood sugar - corresponding transferase D activity; $-\cdot-\cdot \cdot-\mathbf{0}$, corresponding serum growth hormone activity

Transferase activity during a glucose load. The stimulating effect of insulin on the D to I transformation in diabetic leucocytes suggested, that a D to I transformation might be achieved in normal leucocytes, if these were stimulated by insulin. Leucocytes from two normal subjects were therefore isolated before and one or two hours after the intake of 100 grams of glucose, and the homogenate incubated for $60 \mathrm{~min}$ in a similar way as illustrated in Fig. 1. No D to I transformation was, however, elicited, but it was observed that the activity of the $\mathrm{D}$ enzyme increased approx. $60 \%$ in both cases.

Fig. 3 shows the results obtained with leucocytes from two other normal subjects, where the $D$ activity was determined during an oral glucose tolerance test. In each case the activity of the $D$ enzyme closely followed the rise and fall in the blood sugar, but surprisingly a second increase in enzyme activity took place after the blood sugar had returned to basal values. A simultaneous determination of serum growth hormone was therefore included in the second of the experiments, and a considerable increase in growth hormone activity was observed parallel to the second increase in transferase activity.

$A T P-A D P$ and $D$ to $I$ transformation. The stimulating effect of $\mathrm{Mg}^{2+}$ on the $\mathrm{D}$ to I transformation (Fig. 1) was investigated in an experiment with leucocytes from a diabetic patient (IHJ 1967, not included in Table 1), when the control of his diabetes was

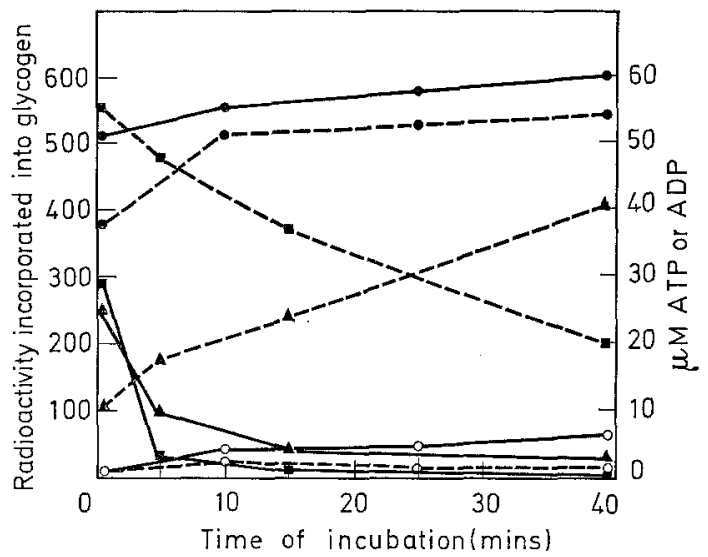

Fig. 4. Influence of $\mathrm{Mg}^{2+}$ on the ATP and ADP concentrations of the incubation mixture, and on the $D$ to $I$ conversion of transferase from leucocytes of a diabetic patient (IHJ, 1967) in a slightly uncontrolled diabetic state. The blood sugar increased from $82 \mathrm{mg} \%$ to $433 \mathrm{mg} \%$, and the leucoeytes were isolated when the fasting blood sugar reached $206 \mathrm{mg} \%$. The conditions of the expt. were as in Fig. 1, except that addition of ATP-Mg was omitted. Enzyme corresponding to $5.5 \times 10^{6}$ leucocytes was used in each assay. $0-\ldots-\ldots, I$ en. zyme; O- $0, \mathrm{I}$ enzyme $+\mathrm{Mg}^{2+} ; \mathbf{0}----\mathbf{0}$ $\mathrm{I}+\mathrm{D}$ enzyme, $\longrightarrow \mathrm{I}+\mathrm{D}$ enzyme $+\mathrm{Mg}^{2+}$; $\mathbf{n}----\mathbf{m}, \mathrm{ATP} ; \mathbf{m}-\mathbf{\mathrm { m }}, \mathrm{ATP}+\mathrm{Mg}^{2+}$; $\mathbf{A}----\mathbf{A}, \mathrm{ADP} ; \mathbf{\Lambda}-\mathbf{A}, \mathrm{ADP}+\mathrm{Mg}^{2+}$

slightly eased (Fig. 4). The D to I transformation was, as expected, very small without $\mathrm{Mg}^{2+}$ added to the incubation mixture. In the experiment without $\mathrm{Mg}^{2+}$ a simultaneous slow decrease in $\mathrm{ATP}$ and increase in ADP concentration occurred, and the ATP + ADP 
concentration only decreased during the last $20 \mathrm{~min}$ of incubation. In the presence of $\mathrm{Mg}^{2+}$, however, the concentration of ATP fell rapidly to very low values within $5 \mathrm{~min}$, and the concentration of ADP showed a similar decline. Apparently, $\mathrm{Mg}^{2+}$ had activated both an ATP-ase and an adenylate kinase.

Since ADP might also be effective in phosphorylating the I enzyme, the posibility of obtaining a further $D$ to $I$ conversion was investigated in an experiment, where an authentic preparation of a $\mathrm{Mg}$ dependent ATP-ase and adenylate kinase from kidney was added to part of the incubated leucocyte homogenate. Addition of the enzymes caused an increase in D to I conversion (Fig. 5). The ATP concentration of

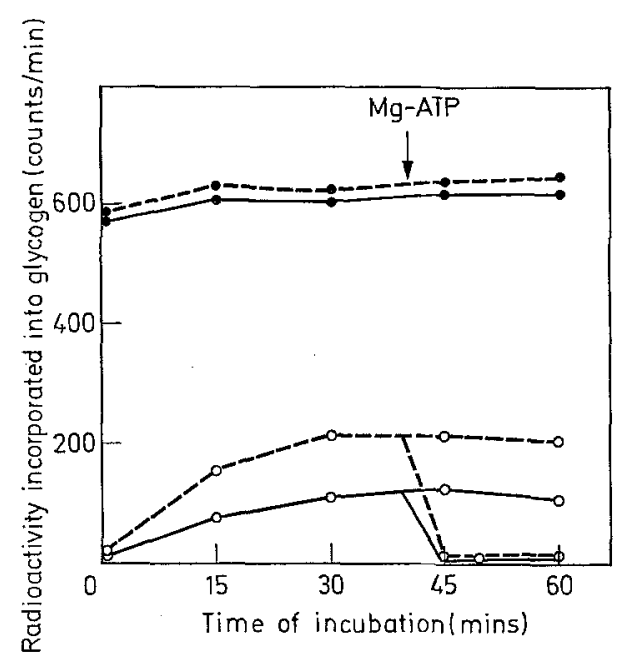

Fig. 5. Effect of a Mg-dependent ATP-ase and adenylate kinase from kidney on the D to I conversion of leucocyte transferase from patient EM. The homogenate contained $1.32 \times 10^{8}$ leucocytes per $\mathrm{ml}$ Tris-EDTA buffer, and was incubated in the presence of mercaptoethanol, $\mathbf{M g}^{2+}$, with or without ATP-ase and adenylate kinase corresponding to an activity of $2 \mu$ moles and $1.3 \mu$ moles ATP $/ \mathrm{min}$, respectively. Otherwise as Fig. 1. The change in total (I -D) activity observed upon addition of ATP-Mg was very small, and has been omitted from the figure.

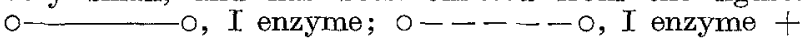
ATP-ase and adenylate kinase; - $\quad I+D$ enzyme; - - - -,$I+D$ enzyme + ATP-ase $+d$

the homogenate fell in both experiments from $53 \mu \mathrm{M}$ to $3 \mu \mathrm{M}$ in $15 \mathrm{~min}$ and to less than $1 \mu \mathrm{M}$ at $30 \mathrm{~min}$. In a comparable experiment done with normal leucocytes, the addition of ATP-ase and adenylate kinase did not elicit D to I transformation, even if the ATP concentration decreased from $43 \mu \mathrm{M}$ to $1.3 \mu \mathrm{M}$ within $15 \mathrm{~min}$.

Kinetic constants. In three experiments no significant difference was found for the kinetic constants: the $K_{m}$ for the substrate UDPG and the $K_{a}$ for the activator glucose-6-phosphate, between leucocytetransferase from insulin-treated and insulin-deprived diabetics. The values were within the limits obtained with transferase from normal cells [14].

\section{Discussion}

The activating effect of $\mathrm{Mg}^{2+}$ on the $\mathrm{D}$ to I transformation was first found in normal human lymphocytes [8], and the present experiments have established a similar effect in human diabetic polymorphonuclear leucocytes, which appears to be best explained by assuming that $\mathrm{Mg}^{2+}$ activates an endogenous ATP-ase and adenylate kinase of the homogenate. The $\mathrm{D}$ to $\mathrm{I}$ transformation observed by adding adenylate kinase, suggested that ADP is also effective in phosphorylating the I enzyme in leucocytes, as has been found in crude muscle preparations [6]. It is possible, however, that $\mathrm{Mg}^{2+}$ in addition stimulates a $\mathrm{Mg}$-dependent synthetase D phosphatase.

The equilibrium between the $D$ and $I$ forms of transferase during an incubation of the leucocyte homogenate, appears determined by the available ATP and ADP. The equilibrium is, however, first displaced in favour of transferase $\mathrm{I}$, when the nucleotide concentration is very low. The phosphorylation of the I enzyme by ATP.Mg is fast, but it has been shown elsewhere [12] with rat PMN leucocytes, that the extent and duration of the $\mathrm{I}$ to $\mathrm{D}$ transformation depends on the amount of added nucleotide.

The transferase of rat muscle has been found shifted in the direction of the I form, when tissue ATP is low [21]. In the circulating leucocytes of diabetics, transferase will presumably be in the $\mathrm{D}$ form, unless the concentration of ATP is very much lower than in the normal leucocyte. The concentration of ATP in the homogenates, which kept the enzyme in the $\mathrm{D}$ form, was $43-56 \mu \mathrm{M}$, which is equivalent to $0.7-1 \mathrm{mM}$, when calculated in terms of cell water. In the normal leucocyte the ATP concentration is approx. $6.5 \mathrm{mM}$ when the cells are in a metabolic steady state [5].

The total enzyme activity often increases during the first $15 \mathrm{~min}$ of incubation, when the ATP concentration of the homogenate falls, and decreases upon addition of ATP-Mg (Fig. 1). This would be consistent with observations that the addition of ATP-Mg inactivates the $\mathbf{D}$ enzyme of muscle and liver of both rat and frog $[18,1]$. The inactivation is enhanced by $3^{\prime}$. $5^{\prime}$-AMP, suggesting the formation of an inactive intermediate which is more phosphorylated than the $D$ form.

The total transferase activity was decreased in leucocytes from untreated diabetics, and corrected by insulin, as formerly also found in liver [20], where the increase in enzyme activity was observed already within two hours. A still faster response was observed in normal leucocytes, where the transferase $D$ activity increased within $30 \mathrm{~min}$ of a glucose load or simultaneously with the known release of endogenous insulin. In previous experiments [4] an increase in glycogen synthesis was first observable $24 \mathrm{~h}$ after insulin administration, and no effect was seen 25 min after insulin given intravenously. These observations need not be contradictory, since the glucose uptake of the leuco- 
cytes was inhibited after the insulin injection, and the concentration of the necessary activator, glucose-6. phosphate, was therefore presumably low.

The $\mathrm{D}$ to I transformation observed in diabetic leucocytes was stimulated by insulin like that of the enzyme in liver and muscle $[22,20,3,23,7]$. As was described in the introduction, insulin may act by forming a less active transferase I kinase, but for leucocytes a stimulating effect on transferase D phosphatase has not been ruled out.

Normal leucoeytes showed no D to I transformation either when stimulated by endogenous insulin, or when the nucleotide level of the homogenate was decreased by adding $\mathrm{Mg}^{2+}$ or ATP-ase and adenylate kinase. This suggests, that normal leucocytes have no transferase D phosphatase, and the presence of this enzyme in diabetic leucocytes might be regarded as related to the disease.

Acknowledgements. The authors are indebted to Professor J.C. Skou for a gift of ATP-ase and adenylate kinase, to Dr. HANS YDE for determining growth hormone activity, and to Dr. HANS RASMUSSEN for the ATP and ADP determinations.

The investigation was supported by grants from Statens Almindelige Videnskabsfond (L 36/65, 171/65), Fonden til Lregevidenskabens Fremmo, F.L. Smidth's fond, P. Carl Petersen's fond, Nordisk Insulinfond, Novo's fond, and Landsforeningen for Sukkersyge. One of the authors (M.R.P.), collaborator of the Instituto "Jaime Ferràn" del C.S.I.C. of Spain, was supported by U.S. Public Health Service Grant AM 10023.

\section{References}

1. Atbert, J.L., M. Roselt Perez, and V. Vintar: Sistemas enzimáticos de biosíntesis de glucógeno en músculo esquelético e hígade de rana. Abstr. of papers. IV Natl. Congr. Spanish Biochem. 31 (1967).

2. Arpers, J.B.: The influence of hexose and insulin on glycogen synthetase in HeLa cells. J. biol. Chem. 241, $217-222(1966)$.

3. BISHOP, J.S., and J. LARNER: Rapid activationinactivation of liver uridine diphosphate glucoseglycogen transferase and phosphorylase by insulin and glucagon "in vivo". J. biol. Chem. 242, 1354-1356 $(1967)$.

4. Esmann, V.: Effect of insulin on human leukocytes. Diabetes 12, 545-549 (1963).

5. Frei, J., C. Borel, and A. Vannotti: Taux leucocytaire des phosphates d'adénosine. Helv. physiol. pharmacol. Acta 19: C 18-19 (1961).

6. Friedman, D.L., and J. Larner: Studies on UDPGglycogen transglucosylase. III. Interconversion of two forms of muscle UDPG- $\alpha$-glucan transglucosylase by a phosphorylation-dephosphorylation reaction sequence. Biochemistry 2, 669-675 (1963).

7. Goldberg, N.D., C. Villar-Patasi, H. Sasko, and J. LARNER: Effects of insulin treatment on muscle 3', 5'-cyclic adenylate levels "in vivo" and "in vitro". Biochim. biophys. Acta 148, 665-672 (1967).

8. Hedeskov, C.J., V. Esmann, and M. Roseld Perez: Glycogen content and UDPGlucose-glucan-glucosyl- transferase activity in normal human lymphocytes. Biochim. biophys. Acta 130, 393-400 (1966).

9. HizuKuri, S., and J. LARNER: Conversion of UDPG $\alpha$-glucan glucosylase from glucose-6-phosphate dependent to independent activity in liver. Biochim. biophys. Acta 73, 525-529 (1963).

10. LARNER, J., and F. SANGER: The amino acid sequence of the phosphorylation site of muscle uridine diphosphoglucose $\alpha$-1,4-glucan $\alpha$-4-glucosyl transferase. J. mol. Biol. 11, $491-500(1965)$.

11. McElrox, W.D.: in S.P. ColowroK and N.O. KaPLAN, Methods in Enzymology, Vol, 6, p. 445. New York: Academic Press 1963.

12. Roselr Perez, M., C.J. Hedeskov, and V. Esmann: Glycogen biosynthesis in leucocytes of normal and alloxan-diabetic rats. Biochim. biophys. Acta 156, $414-417$ (1968).

13. - - - UDPG-glucan-glucosyl transferase in leucocytes of human diabetic patients. Abstr. 2nd meeting, European Ass. Study Diabetes. Diabetologia 2, 217 (1966).

14. Roselu Perez, M., and V. Esmann: UDPG-glucanglucosyl-transferase in human polymorphonuclear leucocytes. Acta chem. scand. 19, 679-684 (1965).

15. - C. Villuar-Patast, and J. Larner: Studies on UDPG-glycogen transglucosylase. I. Preparation and differentiation of two activities of UDPG-glycogen transglucosylase from rat skeletal muscle. Biochemistry 1, 763-768 (1962).

16. - , and J. LARNer: Studies on UDPG- $\alpha$-glucan transglucosylase. IV. Purification and characterization of two forms from rabbit skeletal muscle. Biochemistry 3, 75-81 (1964).

17. - - Studies on UDPG- $\alpha$-glucan transglucosylase. $V$. Two forms of the enzyme in dog skeletal muscle and their interconversion. Biochemistry 3, 81-88 (1964).

18. - - Human UDPG- $\alpha$-glucan transglucosylase. Abstr. Papers, VI Intemational Congr. Biochemistry. VI-98, 595 (1964)

19. Sacristan, A., M. Roselt Perez, and V. Viliar: Estudios sobre la UDPG-glucán transferasa en músculo cardiaco. Abstr. of papers. IV Natl. Congr. Spanish Biochem. 32 (1967).

20. Steiner, D.F., V. Rauda, and R.H. Wirdiays: Effects of insulin, glucagon, and glucocorticoids upon hepatic glycogen synthesis from widine diphosphate glucose. J. biol. Chem. 236, 299-304 (1961).

21. Sövic, O., I. OYYE, and M. Roswll Perez: The effect of anoxia, 2,4-dinitrophenol and 2-deoxyglucose on muscle glycogen synthetase. Biochim. biophys. Acta 124, 26-33 (1966).

22. VItLAR-PALAST, C., and J. LARNER : Insulin treatment and increased. UDPG-glycogen transglucosylase activity in muscle. Areh. biochem. 94, 436-442 (1961).

23. - and J.I. WENGER: In vivo effect of insulin on muscle glycogen synthetase. Identification of the action pathway. Abstr. 1721. Fed. Proc. 26, 563 (1967).

24. YDE, H.: A modified chromatographic technique for the determination of serum growth hormone -the Wick technique. Acta endocr. 58, 123-132, (1968).

Viggo Esmann, M.D.

Department of Medicine

Marselisborg Hospital

University of Aarhus Medical School

Aarhus, Denmark 